\title{
PENDEKATAN ANALISIS SISTEM CAUSAL LOOP DIAGRAM (CLD) DALAM MEMAHAMI UPAYA PEMERINTAH MENINGKATAN AKSES MASYARAKAT TERHADAP PENDIDIKAN TINGGI YANG BERKUALITAS
}

\begin{abstract}
Abdul Haris Abdullah
\section{PENDAHULUAN}

Sistem pendidikan nasional adalah keseluruhan komponen pendidikan yang saling terkait secara terpadu untuk mencapai tujuan pendidikan nasional ${ }^{1}$. Total jumlah penduduk Indonesia pada tahun 2005 adalah sebesar 213.375.287 jiwa. Jumlah penduduk usia 0-19 tahun adalah sebesar 81.762.113 jiwa dengan rincian 41.882.482 jiwa adalah anak laki-laki dan 39.879.631 adalah anak perempuan. Dengan kata lain, anak usia 0-19 tahun memiliki proporsi sebesar 38,32 persen bila dibandingkan dengan keseluruhan populasi penduduk. Usia 19 tahun adalah adalah usia produktif sekaligus masalah ${ }^{2}$. Setiap tahun sekolah lanjutan atas baik SMU maupun SMK sederajat meluluskan siswanya sebanyak dengan jumlah yang terus meningkat. Dari keadaan ini sedikitnya para lulusan tersebut memiliki kehendak melanjutkan studi kejenjang pendidikan tinggi.

Input ini adalah merupakan salah satu instrumen input utama dalam rangka memajukan sumber daya manusia Indonesia menjalani sebuah upaya global tentang Millenium Depelopment Goal (MDGs). Partisipasi pendidikan tinggi dalam hal ini tentu amat strategis sekaligus menjadi taktis. Strategis karena kita ingin memiliki SDM yang baik dalam rangka mengejar ketertinggalan dengan negera-negara lain. Taktis karena pendidikan tinggi dituntut mampu melahirkan generasi baru pendidikan tinggi yang sejalan dengan kepentingan pasar kerja dan bersesuaian dengan potensi sumber daya alam kita.

Kesadaran starategisnya upaya pemerintah kita barangkali tinggal didorong melalui kebijakan dan regulasi yang fleksibel dalam mencapainya. Tetapi persoalan akan makin rumit ketika implementasi taktis tersebut menjadi tanggung jawab otonom institusi pendidikan tinggi. Karenanya institusi pendidikan tinggi seharusnya serius dalam menterjemahkan kebijakan dan regulasi yang telah diupayakan pemerintah.

Kerumitan pemahaman persoalan yang dihadapi membutuhkan kemampuan pemetaan persoalan secara riil dengan beragam cara baik riset ataupun kontrol kualitas yang sungguh-sungguh oleh para pemimpin pendidikan tinggi.
\end{abstract}

\section{PERMASALAHAN}

\footnotetext{
${ }^{1}$ Undang-undang Nomor 20 Tahun 2003 tentang Sistem Pendidikan Nasional

${ }^{2}$ http://www.kotalayakanak.org/dokumen/laporankha/lampiranKHA3dan4.pdf

Pendidikan Untuk Semua (Education For All), Konvensi Hak Anak (Convention on the right of child), Millenium Development Goals (MDGs), World Summit on Sustainable Development
} 
Harapan di atas merupakan tujuan mulia yang patut diapresiasi oleh seluruh komponen bangsa tak terkecuali. Namun harapan membutuhkan tindakan konkrit, strategis serta sistemik, oleh karena itu dalam upaya menuju kepada harapan tersebut kiranya penting memahaminya secara holistik agar kita dapat mengetahui hendaknya dari mana akan dimulai dan sejauh mana harapan tersebut bisa tercapai. Dari identifikasi dapat dirumuskan masalahnya sebagai berikut:

1. Tingkat Pendidikan Penduduk Relatif Masih Rendah.

2. Dinamika perubahan struktur penduduk belum sepenuhnya teratasi dalam pembangunan pendidikan.

3. Masih terdapat kesenjangan tingkat pendidikan yang cukup lebar antar kelompok masyarakat.

4. Fasilitas pelayanan pendidikan khususnya untuk jenjang pendidikan menengah pertama dan yang lebih tinggi belum tersedia secara merata.

5. Kualitas pendidikan relatif masih rendah dan belum mampu memenuhi kebutuhan kompetensi peserta didik.

6. Pembangunan pendidikan belum sepenuhnya dapat meningkatkan kemampuan kewirausahaan lulusan.

7. Pendidikan tinggi masih menghadapi kendala dalam mengembangkan dan menciptakan ilmu pengetahuan dan teknologi.

8. Manajemen pendidikan belum berjalan efektif dan efisien.

Secara sederhana permasalahan kita lihat melalui gambaran Causal Loop Diagram (CLD) sebagai berikut:

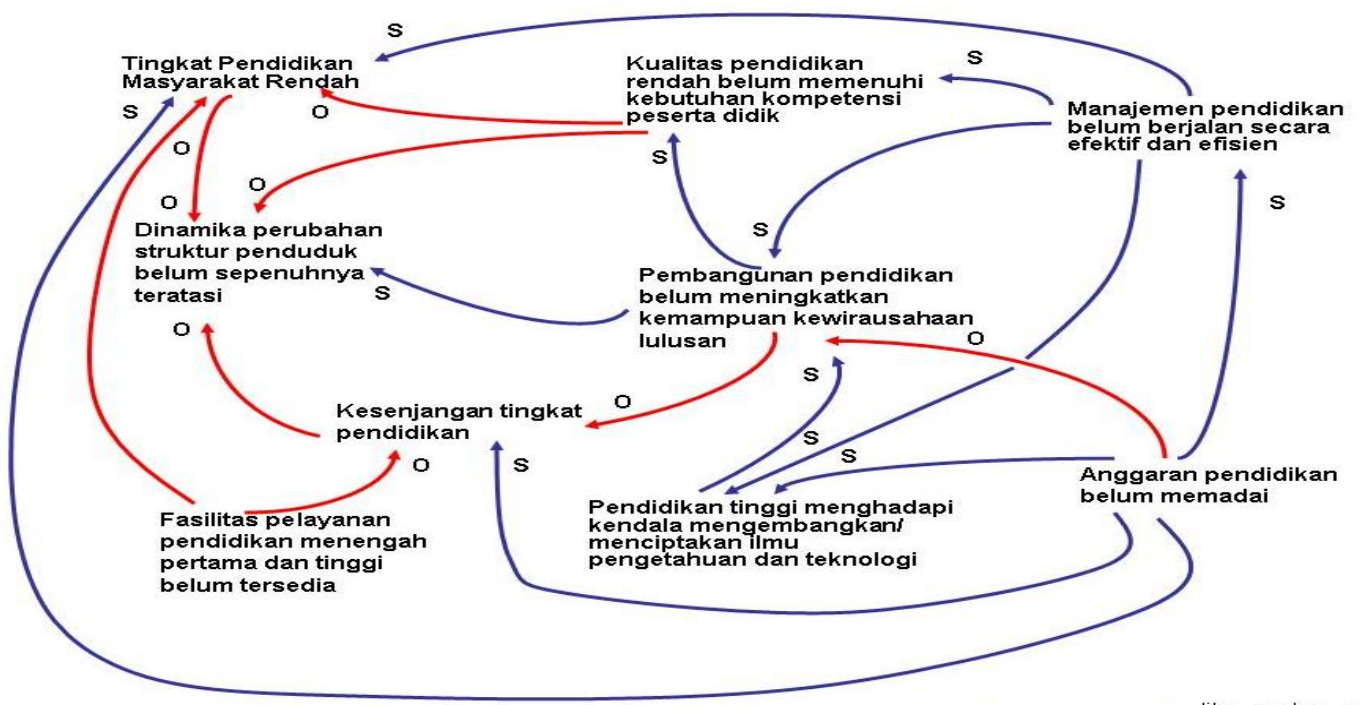




\section{Gambar 1 Permasalahan Pendidikan}

\section{Program Pendidikan Tinggi Pemerintah}

Program ini ditujukan untuk meningkatkan akses dan pemerataan pelayanan pendidikan tinggi baik untuk penduduk laki-laki maupun perempuan yang mencakup program pendidikan diploma, sarjana, magister, spesialis, dan doktor yang diselenggarakan oleh perguruan tinggi yang dapat berbentuk akademi, politeknik, sekolah tinggi, institut atau universitas yang bermutu tinggi dan relevan terhadap kebutuhan pasar kerja, dan mengembangkan ilmu pengetahuan, teknologi, budaya, dan seni sehingga dapat berkontribusi secara optimal pada peningkatan kesejahteraan masyarakat dan daya saing bangsa.

Kegiatan pokok yang dilaksanakan antara lain meliputi ${ }^{3}$ :

1. Percepatan transformasi perguruan tinggi Badan Hukum Milik Negara (BHMN) menjadi perguruan tinggi otonom dan akuntabel dengan penyediaan dan pengembangan infrastruktur hukum guna meningkatkan efektivitas, transparansi, akuntabilitas dan transformasi, sehingga tercipta suasana inovatif dan kreatif;

2. Penyediaan dan pengembangan instrumen hukum berupa peraturan perundang-undangan mengenai perguruan tinggi sebagai badan hukum pendidikan yang bersifat nirlaba dan mempunyai kewenangan mengelola sumber daya secara mandiri untuk menyelenggarakan pendidikan;

3. Penyiapan calon pendidik dan tenaga kependidikan dalam jumlah dan mutu yang sesuai untuk mendukung keberhasilan Wajib Belajar Pendidikan Dasar Sembilan Tahun.

4. Penyediaan sarana dan prasarana pendidikan yang memadai sesuai dengan kebutuhan belajar mengajar termasuk pendidik dan tenaga kependidikan dengan kualifikasi yang sesuai dengan bidang yang dibutuhkan hingga mencapai keadaan yang memungkinkan meningkatnya kualitas proses pembelajaran dan lulusan perguruan tinggi secara berkelanjutan;

\footnotetext{
${ }^{3}$ www.bappenas.go.id/get-file-server/node/172/
} 
5. Pengembangan kurikulum yang mengacu pada standar nasional dan internasional serta pengembangan bahan ajar yang disesuaikan dengan perkembangan jaman dan ilmu pengetahuan, teknologi, budaya, dan seni;

6. Penyediaan materi pendidikan dan media pengajaran termasuk buku pelajaran dan jurnal ilmiah dalam dan luar negeri serta materi pelajaran yang berbasis teknologi informasi dan komunikasi;

7. Penyediaan biaya operasional pendidikan dalam bentuk block grant atau imbal swadaya bagi satuan pendidikan tinggi termasuk subsidi bagi peserta didik yang kurang beruntung tetapi mempunyai prestasi akademis yang baik;

8. Pelaksanaan Tri Dharma Perguruan Tinggi yang mencakup pendidikan, penelitian, dan pengabdian pada masyarakat yang antara lain ditujukan untuk peningkatan kesesuaian pendidikan tinggi dengan kebutuhan masyarakat baik di perdesaan maupun di perkotaan, penerapan otonomi keilmuan yang mendorong perguruan tinggi melaksanakan tugasnya sebagai pengembang ilmu pengetahuan dan teknologi, serta meningkatkan kualitas dan kuantitas serta diversifikasi bidang penelitian di lingkungan perguruan tinggi;

9. Peningkatan kerjasama perguruan tinggi dengan dunia usaha, industri dan pemerintah daerah untuk meningkatkan relevansi pendidikan tinggi dengan kebutuhan dunia kerja dan pengembangan wilayah, termasuk kerjasama dalam pendidikan dan penelitian yang menghasilkan ilmu pengetahuan, teknologi, budaya, dan seni, dan pemanfaatan hasil penelitian dalam rangka meningkatkan kesejahteraan bangsa;

10. Penyediaan informasi pendidikan yang memadai yang memungkinkan masyarakat untuk memilih pendidikan sesuai kualitas yang diinginkan; dan

11. Pengembangan kebijakan, melakukan perencanaan, monitoring, evaluasi, dan pengawasan pelaksanaan pembangunan pendidikan tinggi sejalan dengan prinsip-prinsip transparansi, akuntabilitas, partisipasi, dan demokratisasi. 


\section{Analisis CLD \\ Tentang Model Pendekatan}

Pada pendekatan sistem yang menggunakan model input-output (SMF) pembahasan masalah lebih banyak ditekankan kepada hubungan yang bersifat statis dari sistem. Model input-output memang dapat mendukung penerapan pendekatan sistem dalam merancang dan memperbaiki berbagai sistem organisasi dan manajemen yang pada umumnya keadaannya relatif stabil. Tetapi untuk permasalahan sosial yang luas dan kompleks dan bersifat dinamis, pendekatan statis SMF kurang memadai. Karena sebagaimana kita ketahui pada umumnya sebagian besar sistem kehidupan tidak dalam keadaan statis dan tidak linier hubungan sebab-akibatnya. Dunia kita dalam keadaan selalu bergerak dan berubah atau dinamis dan dunia kelihatannya seperti dalam keadaan tidak teratur.

Tetapi sesungguhnya dibawah permukaan dari keadaan yang tidak teratur itu ada keteraturan. Dalam hal ini yang dimaksud dengan teratur buka berarti tenang, diam, atau baik, tetapi artinya ada suatu kemampuan menyesuaikan diri terhadap pola, bentuk dan strukturnya. Pola dan bentuknya itu diciptakan melalui interaksi atau hubungan yang aktif dari elemen-elemen atau komponen-komponen dari sistem yang bersangkutan.

Jadi bila kita mengalami hal yang tidak teratur, kita perlu bertanya pada diri kita, apa yang sesungguhnya yang terjadi dibawah permukaan, dan hubungan atau keterkaitan, serta pola interaksi seperti apa yang menciptakan struktur dibawahnya yang menyebabkan ketidakaturan itu? Pada sistem yang mempunyai hubungan tidak linier memperlihatkan suatu kebergantungan yang sensitif terhadap kondisi awalnya, artinya jika ada kejadian kecil saja pada salah satu bagian sistem akan dapat menyebabkan turbulensi yang besar kepada bagian sistem yang lainnya. Pada sistem adaptif yang kompleks, perubahan terjadi melalui proses adaptasi. Melalui proses ini suatu pola pengaturan diri yang bam atau bentuk akan muncul dipermukaan.

Berdasarkan pertimbangan di atas maka dalam kita menganalisis dan mencarikan solusi untuk suatu masalah sosial yang pada umumnya bersifat 
dinamis ini, kita harus mampu mendekatinya dengan memperlakukannya sebagai suatu sistem yang dinamis dengan hubungan sebab-akibat yang tidak linier. Pendekatan sistem yang dinamis ini (systems dynamics) merupakan aplikasi dari pemikiran kesisteman yang memfokuskan perhatiannya kepada pola hubungan sebab-akibat yang terjadi karena pengaruh umpan balik dari hasil kegiatan atau kondisi dari komponen sistem yang satu terhadap yang lainnya. Dalam hal ini model Causal Loop Diagram (CLD) yang merupakan salah satu dari model sistem dinamis akan lebih tepat digunakan daripada model input-proses-output yang biasa kita gunakan dalam memecahkan masalah organisasi dan manajemen. Melalui model CLD, seluruh komponen atau variabel yang terlibat baik yang internal dan eksternal dari sistem yang bersangkutan diidentifikasikan. Model CLD menjelaskan bagaimana variabel-variabel dari suatu sistem saling berkaitan. CLD sangat berguna untuk melihat masalah keterkaitan sebab-akibat antara elemen-elemen yang berada pada loop yang bersangkutan, pengaruh faktor elemen yang satu dengan yang lain, termasuk apakah pengaruhnya searah atau berlawanan. Model CLD cocok digunakan untuk mendukung pendekatan sistem terhadap masalah-masalah sistem sosial, politik, ekonomi, pendidikan dan lain sebagainya.

\section{Model Causal Loop Diagram atau CLD}

Model $\mathrm{CLD}^{4}$ ini walaupun bentuk dan pendekatannya berbeda dengan model input-output, tetapi tetap mengacu kepada konsep dan karakteristik sistem. Yaitu bahwa suatu sistem yang terdiri dari banyak komponen yang saling berkaitan dan saling mempengaruhi perlu dilihat secara menyeluruh, bahwa peranan feedback baik yang internal maupun eksternal dari suatu sistem sangatlah penting untuk diperhatikan, dan bahwa sistem sangat dipengaruhi oleh lingkungannya, dan sistem akan entropi (kepunahan) bila tidak ada keseimbangan antara input dan outputnya atau jika ia mengabaikan tuntutan dan pengaruh lingkungannya, dan sebagainya.

Model CLD adalah model yang menekankan perhatiannya kepada hubungan sebab-akibat antar variabel (komponen) sistem yang digambarkan

\footnotetext{
${ }^{4}$ Billy Tunas, Memahami dan Memecahkan Masalah dengan Pendekatan Sistem, tahun 2007
} 
dalam suatu diagram berupa garis lengkung yang berujung tanda panah yang menghubungkan antara komponen sistem yang satu dengan yang lainnya, di mana pada ujung panahnya dibubuhi tanda positif (atau tanda $S$ ) dan negatif (atau tanda O), yang menggambarkan pengaruh variabel yang satu dengan yang lainnya yang berubah-ubah secara dinamis sejalan dengan perkembangan waktu. CLD akan dapat membantu kita menjelaskan dinamika hubungan sebab-akibat yang terjadi dalam suatu sistem yang kompleks.

Tanda S (sameness) menandakan bahwa jika variabel yang mempengaruhi (sebagai penyebab) berubah (misalnya meningkat) maka variabel yang dipengaruhi (sebagai akibat) akan berubah sesuai dengan arah perubahan variabel yang mem-pengaruhinya tadi (yaitu akan meningkat pula). Sedangkan tanda O (oppositeness) akibatnya adalah berlawanan, artinya bila variabel yang mempengaruhinya meningkat, maka variabel yang dipengaruhinya menurun.

Pada CLD panah-panah itu akan membentuk suatu loop dengan diberi tanda $\mathrm{R}$ (reinforcing) dan tanda B (balancing). R berarti saling memperkuat atau memperlemah.

\section{Keuntungan Model CLD}

Keuntungan pendekatan sistem dengan menggunakan model CLD ini antara lain adalah:

- Mendorong kita untuk dapat melihat suatu permasalahan secara menyeluruh, baik dari segi cakupan dan waktu, sehingga dapat mencegah kita dari berpikir yang sempit dan jangka pendek.

- Melalui gambaran rantai hubungan sebab-akibat pada CLD, membuat model mental kita menjadi lebih eksplisit, kepercayaan dasar kita tentang bagaimana dunia bekerja dan dasar bagaimana kita mengambil keputusan dan tindakan akan menjadi lebih baik.

- Dengan adanya CLD memungkinkan model mental kita dapat diketahui dan dibandingkan dengan model mental orang lain terhadap perosalan yang dihadapi, sehingga dapat memberikan dasar terwujudnya kerja sama tim yang lebih baik. Jadi CLD memberikan alat yang efektif untuk komunikasi antara anggota tim. 
- CLD juga akan dapat membantu mengeksplorasi alternatif-alternatif kebijakan dan keputusan sehingga konsekwensi-konsekwensinya dapat diantisipasi lebih dini. Hal ini memungkinkan kita dapat mencegah mengambil keputusan yang terburu-buru, yang kadang-kadang malah menimbulkan bomerang, atau mengambil keputusan yang nantinya akan kita sesalkan.

- Secara keseluruhan pendekatan sistem dengan menggunakan model CLD memungkinkan kita berada pada posisi yang terbaik untuk mengambil keputusan yang teruji dari berbagai kemungkinan dan perubahan waktu.

Petunjuk Memahami Causal Loop Digram (CLD), Sherdood (2002) memberi petunjuk penting dalam memahami CLD untuk suatu permasalahan yaitu: Ketahui batasan dan lingkup masalah; Mulai dari sesuatu (variabel) yang menarik

Melalui CLD kita akan dapat mengetahui faktor-faktor atau variabelvariabel apa saja yang terlibat atau terkait dengan masalah yang kita hadapi termasuk hubungan sebab-akibat antar variabel-variabel yang bersangkutan dalam konteks permasalahan tersebut. Kemudian berdasarkan pengetahuan itu, kita akan dapat memilih dan menentukan tindakan apa yang perlu kita lakukan untuk mengatasi masalah yang dihadapi dan dimana seyogyanya tindakan itu harus dumulai, serta konsekwensi apa saja yang akan ditimbulkan bila tindakan itu kita lakukan. Semakin lengkap dan relevan serta terukur variabel-variabel yang dikemukakan oleh CLD itu, semakin tepat pilihan tindakan yang kita ambil.

\section{Pembahasan Masalah}

1. Kerjasama dengan informasi pendidikan, akuntabilitas, dan kebijakan; Dengan melakukan kerjasama dengan seluruh stakeholder pendidikan maka perguruan tinggi akan meningkatkan penyampaian informasi pendidikan kepada masyarakat pelanggan.Kerjasama pula akan meningkatkan tumbuhnay keprcayaan atau akuntabilitas institusi. Kerjasama juga dapat mengkoreksi kebijakan kepada pelanggan pendidikan ataupun masyarakat umum.

2. Tridarma dengan kerjasama PT, akuntabilitas dan kebijakan; Melakasanakan Tridarma pendidikan tinggi dengannya dapat meningkatkan 
kerjasama antar PT, meningkatkan akuntabilitas atau kepercayaan masyarakat dan dapat melahirkan meningkatnya kebijakan yang memperhatikan kepentingan pengguna perguruan tinggi.

3. ICT dengan partisipasi, demokratisasi, materi pendidikan, penyiapan calon pendidik;

Information comunication technology (ICT) yang memadai akan meningkatkan partisipasi masyarakat dalam kegiatan institusi. ICT juga dapat mendorong tumbuhnya demokratisasi, menignkatkan pemahaman dan, kedalaman, dan keluasan materipendidikan kepada mahasiswa. ICT juga menjadi sebuah komunikasi yang baik dalam peningkatan rekrutmen tenaga pendidikan di lingkungan institusi perguruan tinggi.

4. Materi pendidikan dengan penyiapan calon pendidik dan demokratisasi;

5. Kurikulum dengan materi pendidikan, dan penyiapan penyiapan calon pendidik;

6. Sarana dan prasarana dengan kurikulum dan penyiapan calon pendidik;

7. Instrumen hukum dengan demokratisasi dan penyiapan calon pendidik;

8. Percepatan transformasi dengan demokratisasi dan instrumen hukum;

9. Transparansi dengan demokratisasi dan percepatan transformasi;

10. Pengawasan dengan demokratisasi dan evaluasi;

11. Evaluasi dengan kebijakan dan perencanaan;

12. Monitoring dengan evaluasi dan kebijakan;

13. Perencanaan dengan akuntabilitas dan monitoring;

14. Kebijakan dengan akuntabilitas, perencanaan, percepatan transformasi.

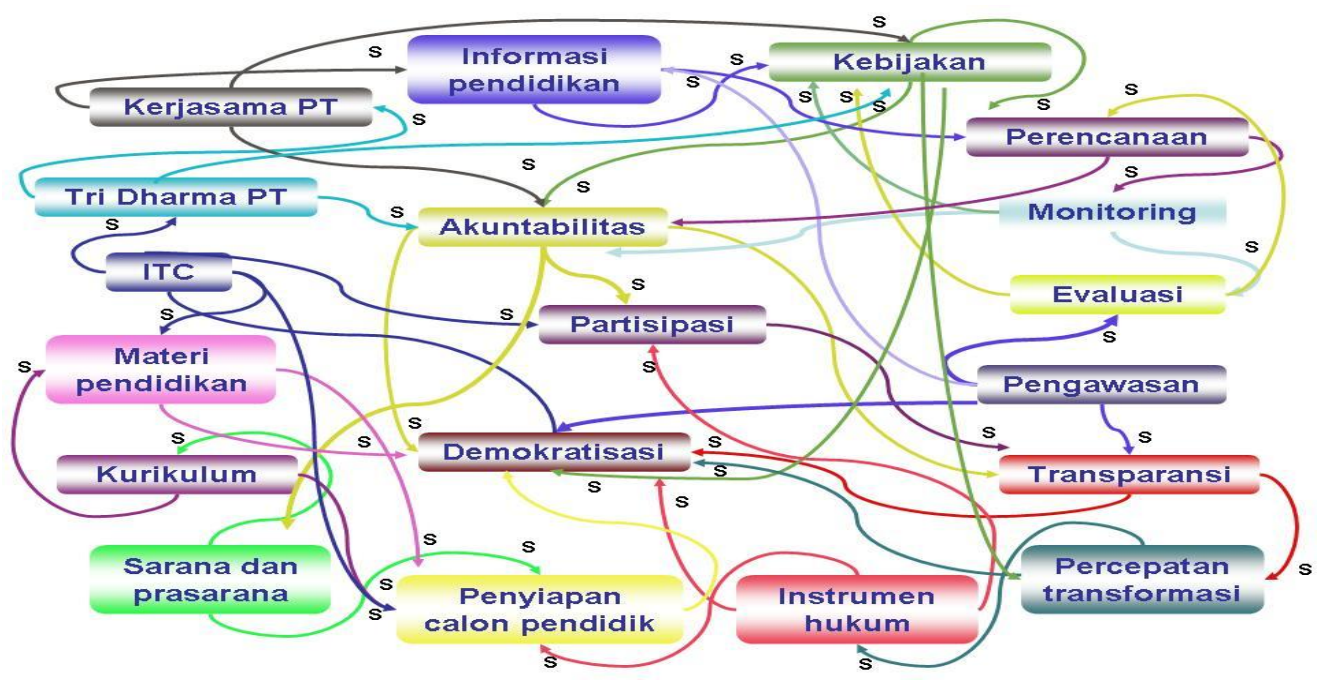




\section{Gambar 2 Causal Loop Diagram Bahasan Masalah}

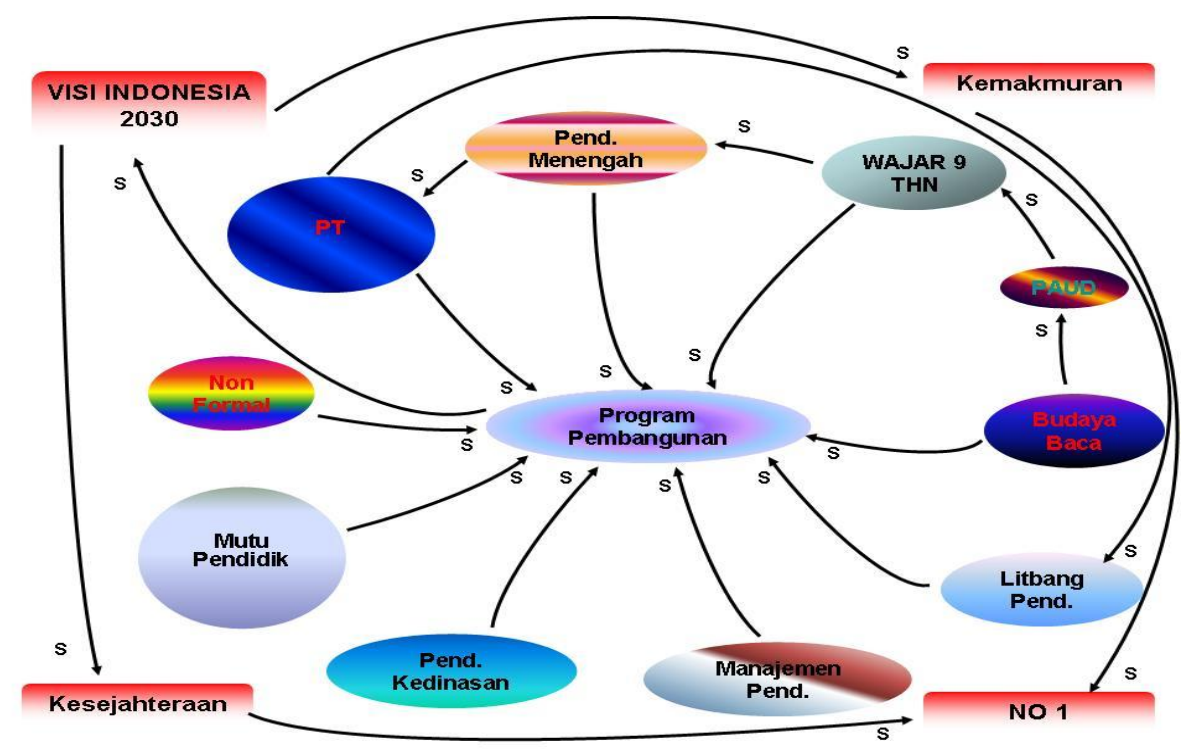

Gambar 3

\section{Visi Pendidikan Berkualitas}

\section{Penutup}

\section{Kesimpulan}

1. Dengan memahami hasil identifikasi Model Sistem Causal Loop Diagram (CLD) nampak jelas bagi kita dari mana dan akan kemanakah arah kebijakan pembangunan bidang pendidikan khususnya usaha pemerataan akses pendidikan yang berkualitas di Indonesia.

2. Dengan pendekatan sistem ini pula bahwa sesungguhnya apa yang akan dilakukan dan dari mana akan dimulai usaha pemerataan pendidikan berkualitas kita sudah dapat menebaknnya dengan tingkat akurasi mengikuti urut-urutan dari identifikasi yang telah ada. 
3. Pendekatan Model Causal Loop Diagram (CLD) sekalipun telah membantu melakukan identifikasi sistemik, namun perlu lagi untuk dilanjutkan dengan model-model lain untuk dapatnya sebuah analisis sistem bersinergi menjawab masalah yang sesungguhnya. Misalnya analisis sistem dengan pendekatan Venn Diagram sebagai kelanjutan untuk memahami varian-varian yang ada dengan mengontrolnya memberikan angka-angka matematis yang dapat dikalkulasi, sehingga akan tiba pada pemilihan keputusan menangani masalah secara tepat.

\section{Saran}

1. Kepada pemerintah kebijakan-kebijakan yang selalu diproduk baiknya dianalisis dengan pendekatan sistem agar apa yang menjadi kebijakan antar departemen dapat bersinergi dan tidak nampak tumpang tindih atau mengalami ambigui di masyarakat.

2. Kepada para akademisi pemikir dan sekaligus penyelaras bagi kehidupan berbangsa penting untuk memberikan sumbangan yang benar-benar logis agar usaha bersama untuk kesejahteraan rakyat selalu membumi dan jauh dari sengketa politik-politikan.

3. Analisis sistem baiknya menjadi mata pembelajaran untuk para pengambil kebijakan di negeri ini sebelum melaksanakan tugas kenegaraan.

\section{DAFTAR PUSTAKA}

1. Billy Tunas, Memahami dan Memecahkan Masalah dengan Pendekatan Sistem, tahun 2007

2. Pendidikan Untuk Semua (Education For All), Konvensi Hak Anak (Convention on the right of child), Millenium Development Goals (MDGs), World Summit on Sustainable Development

3. Undang-undang Nomor 20 Tahun 2003 tentang Sistem Pendidikan Nasional 